\begin{tabular}{|l|l|l||}
\hline \multicolumn{2}{|c|}{ PublisherInfo } \\
\hline \hline PublisherName & $:$ & BioMed Central \\
\hline \hline PublisherLocation & $:$ & London \\
\hline \hline PublisherImprintName & $:$ & BioMed Central \\
\hline \hline
\end{tabular}

\title{
Transcriptional switch
}

\begin{tabular}{|l|l|l||}
\hline \multicolumn{2}{|c|}{ ArticleInfo } \\
\hline \hline ArticleID & $:$ & 4177 \\
\hline \hline ArticleDOI & $:$ & $10.1186 /$ gb-spotlight-20010815-01 \\
\hline \hline ArticleCitationID & $:$ & spotlight-20010815-01 \\
\hline \hline ArticleSequenceNumber & $:$ & 248 \\
\hline \hline ArticleCategory & $:$ & Research news \\
\hline ArticleFirstPage & $:$ & 1 \\
\hline \hline ArticleLastPage & $:$ & 2 \\
\hline \hline & & RegistrationDate : 2001-08-15 \\
ArticleHistory & $:$ & OnlineDate $\quad$ 2001-08-15 \\
\hline \hline ArticleCopyright & $:$ & BioMed Central Ltd2001 \\
\hline \hline ArticleGrants & $:$ & \\
\hline \hline ArticleContext & $:$ & 130592211 \\
\hline \hline
\end{tabular}




\section{Jonathan B Weitzman}

Email: jonathanweitzman@hotmail.com

Transcription is regulated by the coordinated assembly of protein complexes that synergize to switch on gene expression. The virally induced enhanceosome of the interferon- $\beta$ (IFN- $\beta$ ) gene is one of the best characterized transcriptional switches. In the August 10 Science, Nikhil Munshi and colleagues from Columbia University describe how acetylation of the architectural high-mobility-group protein HMGI(Y) regulates stability of the IFN- $\beta$ enhanceosome (Science 2001, 293:1133-1136). The $\mathrm{HMGI}(\mathrm{Y})$ protein is a target for acetylation by two different enzymes (CBP and PCAF/GCN5) on distinct lysine residues (Lys65 and Lys71, respectively). Munshi et al. mutated Lys71 and observed decreased virus-induced transcription and reduced interaction with enhanceosome proteins. They propose that $\mathrm{HMGI}(\mathrm{Y})$ acetylation by PCAF/GCN5 facilitates enhanceosome assembly. They performed chromatin immunoprecipitation experiments to demonstrate that $\mathrm{K} 71$ acetylation coincides with enhanceosome assembly and activation (3 hours-post infection), whereas Lys65 acetylation occurred at the time of enhanceosome disruption (after 6 hours). Also, Lys 71 acetylation decreased the efficiency of CBP acetylation on Lys65. Munshi et al. propose a model in which the ordered recruitment of, and acetylation by, PCAF/GCN5 followed by CBP regulates enhanceosome stability (assembly and disassembly, respectively) and the transcriptional switch.

\section{References}

1. Virus induction of human IFN beta gene expression requires the assembly of an enhanceosome

2. Science, [http://www.sciencemag.org]

3. Columbia University, [http://www.columbia.edu] 